\title{
UPAYA MENINGKATKAN HASIL BELAJAR IPA PESERTA DIDIK \\ DENGAN MODEL PEMBELAJARAN MIND MAPPING PADA \\ KELAS V SDN 1 SAKA LAGUN KABUPATEN KAPUAS \\ TAHUN PELAJARAN 2016/2017
}

\section{OLEH : Basuki Rahman*Dr. Rita Rahmaniati, M.Pd}

\begin{abstract}
Abstrak
Penelitian ini bertujuan untuk : (1) Meningkatkan aktivitas belajar IPA dengan meggunakan model pembelajaran mind mapping, (2) Meningkatkan hasil belajar IPA dengan meggunakan model pembelajaran mind mapping.

Metode yang digunakan peneliti adalah menggunakan rancangan Penelitian Tindakan Kelas (PTK) yang berusaha memecahkan atau menjawab permasalahan yang dihadapi pada situasi sekarang. Subjek dalam penelitian ini adalah seluruh peserta didik kelas V SDN 1 Saka Lagun Kabupaten Kapuas yang terdiri dari 19 orang peserta didik, 9 orang laki-laki dan 10 orang perempuan. Untuk teknik pengumpulan data yang digunakan adalah oservasi dan tes. Sedangkan dalam penelitian ini meggunakan analisis nilai rata-rata kelas dan persentase ketuntasan belajar klasikal.

Hasil penelitian ini menunjukkan bahwa : (1) Aktivitas belajar peserta didik kelas V SDN 1 Saka Lagun Kabupaten Kapuas dalam proses pembelajaran IPA dengan menggunakan model pembelajaran mind mapping dikategorikan baik. Hal ini dibuktikan dengan hasil aktivitas peserta didik dalam mengikuti proses pembelajaran IPA dan dikategorikan baik dengan nilai rata-rata sebesar 2,9 pada sklus I dan meningkat menjadi 3,6 pada siklus II. (2) Ada peningkatan hasil belajar IPA dengan menggunakan model pembelajaran mind mapping pada peserta didik kelas V SDN 1 Saka Lagun Kabupaten Kapuas. Peningkatan tersebut dapat dilihat dari hasil belajar peserta didik pada mata pelajaran IPA khususnya pada materi peristiwa alam di Indonesia. Pada siklus I perolehan nilai rata-rata peserta didik 67 dengan ketuntasan klasikal 79\% dan mengalami peningkatan pada siklus II dengan nilai rata-rata 79 dan ketuntasan klasikal 95\%.
\end{abstract}

Kata Kunci : Hasil Belajar, IPA, Model Pembelajaran Mind Mapping.

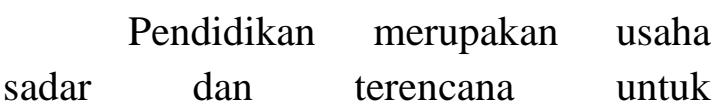
mengembangkan potensi diri manusia serta keterampilan yang diperlukan dirinya, masyarakat, bangsa dan negara (Dwi Siswoyo, 2007:19). Pendidikan mempunyai peran yang sangat strategis dalam meningkatkan kualitas sumber daya manusia, seperti yang tercantum dalam Undang-Undang Sistem Pendidikan Nasional No. 20 tahun 2003 Bab 2 Pasal 3:

\section{PENDAHULUAN}

Pendidikan nasional bertujuan untuk berkembangnya potensi didik agar menjadi manusia yang beriman dan bertakwa kepada Tuhan Yang Maha Esa, berakhlak mulia, sehat, berilmu, cakap, kreatif, mandiri, dan menjadi warga negara yang demokratis serta bertanggung jawab.

Pendidikan nasional perlu berjalan sesuai dengan tujuan yang ingin dicapai. Pencapaian tujuan pendidikan tersebut, 
dapat terbentuk melalui pendidikan dasar. Hal ini sesuai dengan Peraturan Menteri Pendidikan Nasional nomor 3 tahun 2006 tanggal 23 Mei 2006 yang menyatakan bahwa pendidikan dasar bertujuan untuk meletakkan dasar kecerdasan pengetahuan, kepribadian, akhlak mulia, serta keterampilan untuk hidup mandiri dan mengikuti pendidikan lebih lanjut. Salah satu instansi pendidikan dasar tersebut adalah sekolah dasar (SD).

Dari keseluruhan proses di sekolah dasar (SD), kegiatan belajar merupakan kegiatan utama. Hal ini berarti berhasil atau tidaknya pencapaian tujuan pembangunan nasional banyak tergantung pada proses pembelajaran yang dijalani oleh peserta didik. Belajar memerlukan kesiapan peserta didik dalam mengikuti pelajaran di kelas maupun belajar secara mandiri di rumah. Berkaitan dengan kesiapan belajar, salah satu hal penting yang perlu diperhatikan adalah kesiapan fisik dan mental. Kesiapan mental yang dapat mempengaruhi proses belajar diantaranya: 1) intelegensi, 2) minat, 3) kesiapan, 4) kematangan, dan 5) perhatian /konsentrasi (Oemar Hamalik, 2005: 21). Sejalan dengan hal tersebut, Dimyati dan Mudjiono dalam Sugihartono (2007:156) mengemukakan bahwa faktor internal yang mempengaruhi prestasi belajar meliputi: sikap terhadap belajar, motivasi belajar, konsentrasi belajar, mengolah bahan ajar, menyimpan perolehan hasil belajar, dan sebagainya. Dari beberapa faktor tersebut, salah satu faktor yang dapat mempengaruhi proses belajar adalah konsentrasi belajar.

Konsentrasi belajar sangat besar pengaruhnya terhadap hasil belajar. Konsentrasi penuh pada peserta didik akan membuat peserta didik tersebut dapat menangkap materi yang sedang diajarkan. Hal ini sejalan dengan pendapat Prayitno (1997: 28) yang menyatakan bahwa konsentrasi dapat membuat seseorang menguasai apa-apa yang dipelajarinya, karena dengan konsentrasi seluruh perhatian akan tertuju pada apa yang sedang menjadi perhatiannya. Dari hal tersebut, tentunya ketika konsentrasi belajar peserta didik meningkat, maka hasil belajarnya pun akan meningkat juga.

Hendra Surya (2006: 11) menyatakan bahwa bermutu atau tidaknya suatu kegiatan belajar atau optimalnya hasil belajar sangat tergantung pada intensitas kemampuan kita untuk melakukan konsentrasi belajar. Konsentrasi belajar itu tidak datang dengan sendirinya atau bukan dikarenakan pembawaan bakat seseorang yang dibawa sejak lahir, melainkan harus diciptakan dan direncanakan serta dijadikan kebiasaan belajar. Daya konsentrasi belajar pada anak sekolah dasar dapat dikembangkan pada kelas atas (Sugiyanto, 2012: 3-4). Meski bukan gangguan serius, akan tetapi kurang konsentrasi pada anak tidak boleh dibiarkan berlarut-larut. Tanpa penanganan apa pun, masalah ini bisa menetap sampai usia selanjutnya dan semakin sulit untuk ditangani. Ratih Zulhaqqi (2013:1) menyatakan bahwa untuk mengetahui seberapa lama rentang waktu kemampuan konsentrasi seseorang, rumusnya adalah 3-5 menit dikalikan usia. Jadi, misalnya pada anak usia 10 tahun, kemampuan berkonsentrasi idealnya adalah 30-50 menit. Anak yang mencapai batas minimal kurang dari rentang waktu tersebut boleh dikatakan memiliki konsentrasi rendah. 
Dengan demikian, pembelajaran pada anak usia SD perlu dilaksanakan sedemikian rupa sehingga memungkinkan anak dapat meningkatkan proses belajar yang berpengaruh terhadap hasil belajar anak. Salah satu proses belajar yang perlu ditingkatkan yaitu kemampuan berkonsentrasi dalam menerima materi yang diajarkan.

Kemampuan berkonsentrasi diperlukan dalam mengikuti semua mata pelajaran, termasuk Ilmu Pengetahuan Alam (IPA). IPA merupakan mata pelajaran yang diajarkan di sekolah dasar. Pelaksanaan pembelajaran khususnya IPA mengharuskan para guru untuk meningkatkan kemampuan dan mengembangkan keahlian untuk mendapatkan hasil belajar yang optimal. Salah satu kemampuan yang diperlukan dalam pembelajaran IPA adalah kemampuan berkonsentrasi dalam menerima pelajaran. Hal ini sejalan dengan implementasi teori perkembangan Piaget dalam pembelajaran, yaitu guru bertugas untuk memusatkan perhatian kepada peserta didik agar fokus dalam belajar (Harsono, 1993: 74). Diperjelas pula oleh pendapat Usman Samatowa, (2010: 9) yang menyatakan bahwa dalam pembelajaran IPA peserta didik harus memfokuskan diri untuk menerima materi yang sedang diajarkan. Pemfokusan diri tersebut dimaksudkan untuk mengembangkan sikap ingin tahu dan memudahkan anak bersikap logis.

Dengan demikian, diperlukan suatu konsep pendidikan yang dapat memfasilitasi antara kesesuaian dengan perkembangan anak sekolah dasar, sifatsifat anak usia sekolah dasar, maupun hasil belajar khususnya pada pembelajaran IPA. Sri Sulistyorini (2007: 8-9) mengemukakan bahwa konsep pendidikan dalam pembelajaran IPA yang digunakan adalah sebagai berikut.

1. Pendekatan atau metode
pembelajaran harus memberi
kemungkinan agar anak dapat
menunjukkan keaktifan penuh dalam
belajar (active learning);

2. Proses pendidikan yang diciptakan dari suatu metode harus menciptakan suasana menyenangkan bagi anak sehingga ia dapat belajar secara nyaman dan gembira (joyful learning); dan

3. Proses pendidikan yang dirancang harus memberikan kemudahan bagi anak untuk mengeksplorasi lingkungan dan segala sumber belajar lainnya.

Berdasarkan teori di atas, maka metode pembelajaran yang digunakan guru harus dapat membantu peserta didik untuk aktif dalam belajar, menciptakan rasa nyaman, dan mengembangkan kemampuan kerja otak peserta didik. Oleh karena itu, diperlukan suatu metode pembelajaran guna mencapai tujuan pembelajaran IPA khususnya untuk mengembangkan konsentrasi belajar.

Berdasarkan hasil observasi di SDN 1 Saka Lagun Kabupaten Kapuas, pada proses pembelajaran IPA terlihat peserta didik tidak bersemangat terhadap pelajaran yang diajarkan oleh pendidik, sehingga suasana saat belajar kurang menyenangkan dan tidak efektif. Hal ini diidentifikasikan dari hasil belajar yang belum memenuhi kriteria ketuntasan minimum (KKM). Metode pembelajaran IPA yang disampaikan oleh pendidik masih kurang bervariasi dalam proses pembelajaran dan hasil belajar IPA kelas V memperoleh nilai dibawah kriteria ketuntasan minimal. Hal ini terlihat dari 
hasil belajar IPA peserta didik kelas V SDN 1 Saka Lagun yang masih belum mencapai nilai standar kriteria ketuntasan minimal (KKM) yaitu 55. Diketahui bahwa dalam proses pembelajaran IPA pada kelas V nilai yang diperoleh peserta didik masih ada yang dibawah nilai 55. Dimana jumlah peserta didik 19 orang sekitar 59,4\% yaitu 10 orang peserta didik masih dibawah nilai kriteria ketuntasan minimal (KKM) dan sekitar 40,6\% yaitu 9 orang peserta didik yang mencapai kriteria ketuntasan minimal (KKM).

Dari fenomena diatas dapat disimpulkan bahwa rendahnya hasil belajar IPA peserta didik karena kurangnya variasi model pembelajaran, maka hendaknya guru mampu memilih dan mampu menerapkan model pembelajaran yang mampu merangsang peserta didik lebih aktif dalam belajar IPA, yaitu dengan menggunakan model pembelajaran peta pikiran (mind mapping).

Mind Mapping ditemukan dan dikembangkan oleh Tony Buzan seorang peneliti Inggris yang mengaplikasikan pengetahuan tentang otak dan proses berfikir dalam berbagai bidang kehidupan. Mind Mapping merupakan cara termudah menempatkan informasi ke dalam otak dan mengambil informasi keluar dari otak, cara mencatat kreatif, efektif, secara harfiah memetakan pikiran-pikiran kita

\section{KAJIAN TEORI}

\section{A. Pengertian Hasil Belajar}

Hasil belajar adalah kemampuan yang dimiliki siswa setelah menerima pengalaman belajar. Pengertian hasil belajar tidak dapat dipisahkan dari apa yang terjadi di dalam kegiatan belajar baik di kelas, di sekolah maupun di luar sekolah. Apa yang dialami siswa dalam dengan sangat sederhana (Buzan, 2007: 4).

Metode Mind Mapping dapat dijadikan alternatif solusi untuk meningkatkan konsentrasi belajar khususnya pada pembelajaran IPA. Hal tersebut dikarenakan tujuan Mind Mapping menurut Michael Michalko (dalam Buzan, 2007: 6) adalah: 1) mengaktifkan seluruh otak, 2) membereskan akal dari kekusutan mental, 3) memungkinkan kita berfokus untuk pokok bahasan, 4) membantu menunjukkan hubungan antara bagianbagian informasi yang saling terpisah, 5) memberi gambaran yang jelas pada keseluruhan dan perincian, 6) memungkinkan kita mengelompokkan konsep, membantu kita membandingkannya, dan 7) mensyaratkan kita untuk memusatkan pada pokok bahasan yang membantu mengalihkan informasi tentangnya dari ingatan jangka pendek ke ingatan jangka panjang.

Berdasarkan kondisi tersebut, maka peneliti tertarik untuk melakukan Penelitian Tindakan Kelas (PTK) dengan judul "Upaya Meningkatkan Hasil Belajar IPA Peserta Didik Dengan Model Pembelajaran Mind Mapping Pada Kelas V SDN I Saka Lagun Kabupaten Kapuas Tahun Pelajaran 2016/2017".

proses pengetahuan kemampuannya merupakan apa yang diperolehnya (Nana Sudjana, 2004: 3).

Menurut Dimyati dan Mudjiono (1999: 250- 251), hasil belajar merupakan hal yang dapat dipandang dari dua sisi yaitu sisi siswa dan dari sisi guru. Dari sisi siswa, hasil belajar merupakan tingkat perkembangan mental yang lebih baik bila dibandingkan pada 
saat sebelum belajar. Tingkat perkembangan mental tersebut terwujud pada jenis-jenis ranah kognitif, afektif, dan psikomotor. Sedangkan dari sisi guru, hasil belajar merupakan saat terselesaikannya bahan pelajaran.

Horward Kingsley membagi tiga macam hasil belajar, yakni (a) keterampilan dan kebiasaan, (b) pengetahuan dan pengertian, (c) sikap dan cita-cita. Dari pendapat ini menunjukkan hasil perubahan dari semua proses belajar. Hasil belajar ini akan melekat terus pada diri siswa karena sudah menjadi bagian dalam kehidupan siswa tersebut (Nana Sudjana, 2004: 22).

Dari penjelasan di atas, maka dapat disimpulkan bahwa hasil belajar adalah kemampuan yang dimiliki siswa setelah menerima pengalaman belajar baik di dalam kelas maupun di luar kelas yang meliputi ranah kognitif, afektif, psikomotor.

\section{B. Hakikat IPA}

Ilmu Pengetahuan Alam sering disebut sebagai sains yang berasal dari kata Latin Scientia yang berarti: a) pengetahuan tentang atau tahu tentang, dan b) pengetahuan, pengertian, faham yang benar dan mendalam (Surjani Wonorahardjo, 2010: 11). Maskoeri Jasin (2010: 1) menyatakan bahwa IPA merupakan ilmu pengetahuan yang mengkaji tentang gejala-gejala dalam alam semesta, termasuk bumi sehingga terbentuk konsep dan prinsip. Jadi, secara singkat IPA dapat diartikan sebagai ilmu pengetahuan yang mengkaji tentang alam semesta beserta segala isinya.

IPA merupakan bagian dari ilmu pengetahuan yang terdiri dari fakta-fakta, konsep-konsep, prinsipprinsip, dan teori-teori yang merupakan produk dari proses ilmiah (Usman Samatowa, 2010: 19). Namun demikian, IPA bukan hanya sebuah produk, melainkan juga sebagai proses yang menghubungkan sistem, metode, atau proses pengamatan, pemahaman dan penjelasan tentang alam. Lebih jelasnya Carin dan Sund dalam Usman Samatowa (2010: 20) mengemukakan bahwa IPA terdiri dari tiga macam, yaitu:

a. Proses atau metode yang meliputi pengamatan, membuat hipotesis, merancang dan melakukan percobaan, mengukur dan proses-proses pemahaman kealaman lainnya.

b. Produk meliputi prinsip-prinsip, hukum-hukum, teori-teori, kaidahkaidah, postulat-postulat dan sebagainya.

c. Sikap, misalnya mempercayai, menghargai, menanggapi, menerima dan sebagainya.

\section{Tinjauan Tentang Mind Mapping}

Konsep Mind Mapping asal mulanya diperkenalkan oleh Tony Buzan tahun 1970-an. Mind Mapping atau Peta Pikiran adalah alternatif pemikiran keseluruhan terhadap pemikiran linier. Metode Mind Mapping menggapai pikiran dari segala arah dan sudut (Michael Michalko dalam Buzan, 2007:2).

Senada dengan pemikiran tersebut, Buzan mengungkapkan bahwa Mind Mapping adalah alat berpikir kreatif yang mencerminkan cara kerja alami otak dan cara termudah untuk menempatkan informasi ke dalam otak serta mengambil informai ke luar otak. 
Selain itu, Mind Mapping juga merupakan cara mencatat yang kreatif, efektif yang akan memetakan pikiranpikiran kita (Tony Buzan, 2007: 4).

Bentuk Mind Mapping seperti peta sebuah jalan di kota yang mempunyai banyak cabang. Seperti halnya peta jalan kita bisa membuat pandangan secara menyeluruh tentang pokok masalah dalam suatu area yang sangat luas. Dengan sebuah peta kita bisa merencanakan sebuah rute yang tercepat dan tepat dan mengetahui kemana kita akan pergi dan dimana kita berada (Taufik Bahaudin,1999: 53).

Senada dengan hal tersebut, Tony Buzan (2007:6) juga mengemukakan bahwa Mind Mapping bisa dibandingkan dengan peta kota yaitu bagian tengah Mind Map sama halnya dengan pusat kota yang mewakili gagasan terpenting; jalan-jalan protokol yang memancar keluar dari pusat kota yang merupakan pikiran utama dalam proses berpikir, jalan-jalan atau cabang-cabang sekunder merupakan pikiran sekunder.

D. Penelitan yang relevan

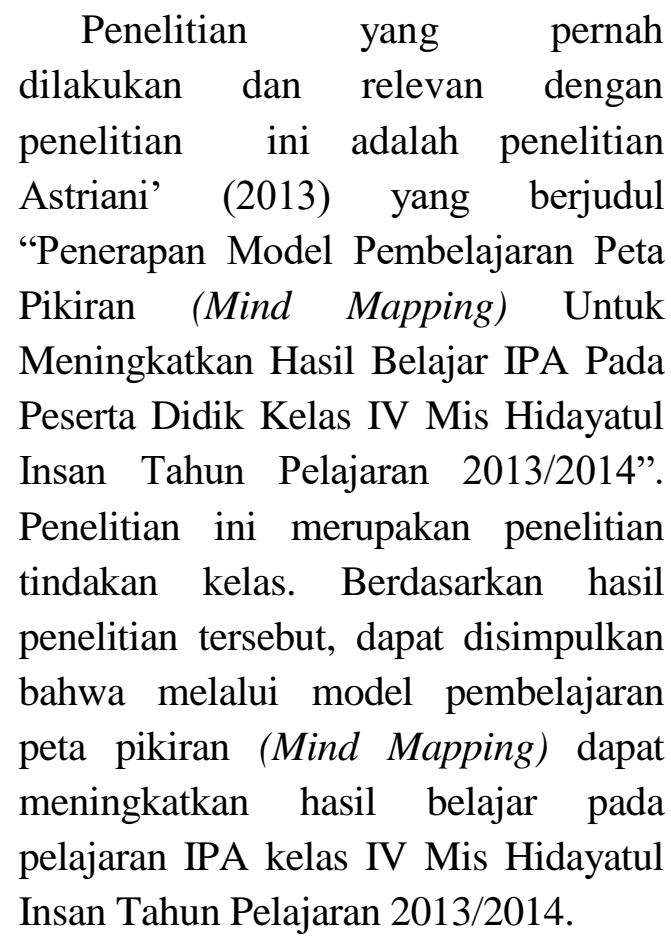

Penelitian kedua yang relevan dengan penelitian ini adalah penelitian Nur Dani Rumanti‘ (2014) yang berjudul "Pengaruh Penerapan Mind Map terhadap Hasil Belajar Kognitif Ilmu Pengetahuan Alam pada Siswa Kelas IV SD Gugus Hasannudin Kecamatan Mertoyudan Kabupaten Magelang Tahun Pelajaran 2013/2014". Penelitian ini merupakan penelitian eksperimen. Berdasarkan hasil penelitian tersebut, dapat disimpulkan bahwa Mind Map dapat mempengaruhi peningkatan hasil belajar kognitif ilmu pengetahuan alam pada siswa kelas IV SD Gugus Hasannudin Kecamatan Mertoyudan Kabupaten Magelang.

\section{METODE PENELITIAN}

Jenis penelitian yang digunakan dalam penelitian ini adalah penelitian tindakan kelas (PTK) yang bertujuan untuk melakukan perbaikan-perbaikan terhadap sistem, isi, dan kompetensi atau situasi pembelajaran dengan menguji cobakan suatu ide ke dalam praktik dan situasi nyata dalam proses belajar mengajar di kelas dengan harapan kegiatan tersebut dapat meningkatkan hasil proses belajar mengajar. Penelitian ini dilaksanakan pada bulan April sampai dengan bulan Juni tahun pelajaran 2016/2017.

Subyek dari peelitian ini adalah Peserta Didik kelas V SDN 1 Saka Lagun Kabupaten Kapuas, yang berjumlah 19 Peseta didik. Faktor yang diteliti yaitu penggunaan model pembelajaran mind mapping untuk meningkatkan hasil belajar pada mata pelajaran IPA. Data yang diperoleh dengan metode observasi dan tes. 
Data yang diperoleh berupa data Kualitatif dan kuantitatif.

\section{HASIL DAN PEMBAHASAN}

\begin{tabular}{|c|c|c|c|c|c|c|c|}
\hline \multirow{2}{*}{$\begin{array}{l}\mathbf{N} \\
\mathbf{0}\end{array}$} & \multirow{2}{*}{ Aktivitas } & \multicolumn{2}{|c|}{$\begin{array}{l}\text { Siklus } \\
\text { I }\end{array}$} & \multirow{2}{*}{$\begin{array}{l}\text { Rat } \\
\text { a- } \\
\text { rat } \\
\text { a }\end{array}$} & \multicolumn{2}{|c|}{$\begin{array}{l}\text { Siklus } \\
\text { II }\end{array}$} & \multirow{2}{*}{\begin{tabular}{|l} 
Rat \\
a- \\
rat \\
a
\end{tabular}} \\
\hline & & p- & $\begin{array}{l}\text { p- } \\
2\end{array}$ & & $\begin{array}{l}p \\
-1\end{array}$ & $\begin{array}{l}p \\
-2\end{array}$ & \\
\hline 1 & $\begin{array}{l}\text { Aktivitas } \\
\text { Guru }\end{array}$ & 3 & $\begin{array}{l}3, \\
06\end{array}$ & $\begin{array}{l}3,0 \\
3 \\
\end{array}$ & $\begin{array}{l}3, \\
7\end{array}$ & $\begin{array}{l}3, \\
6\end{array}$ & 3,7 \\
\hline 2 & $\begin{array}{l}\text { Aktivitas } \\
\text { Peserta } \\
\text { Didik }\end{array}$ & 0 & $\begin{array}{l}3, \\
06\end{array}$ & 2,9 & $\begin{array}{l}3 \\
6\end{array}$ & $\begin{array}{l}3 \\
6\end{array}$ & 3,6 \\
\hline
\end{tabular}

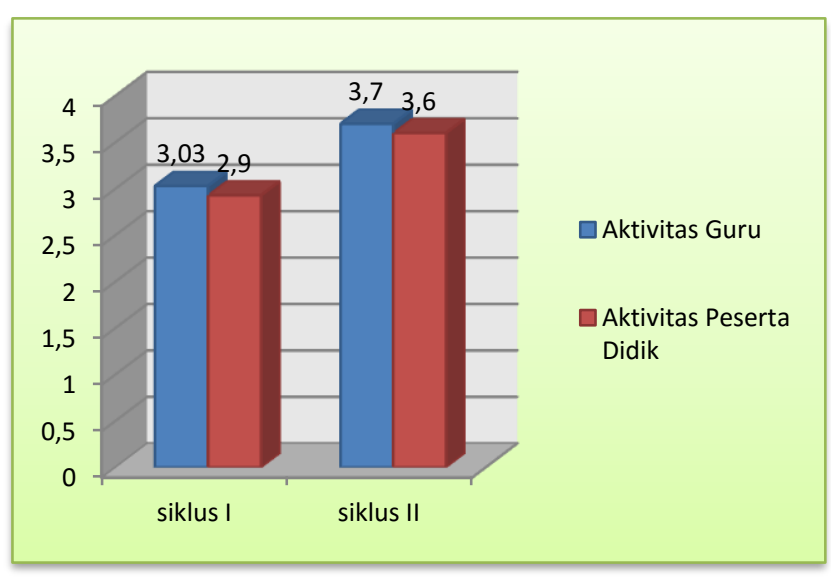

Gambar 1. Diagram rekapitulasi data observasi aktivitas guru dan peserta didik Pada siklus I dan Siklus II
A. Hasil Pengamatan Aktivitas Guru dan Peserta Didik Selama Pembelajaran

Tabel 1. Data Hasil Pengamatan Aktivitas Guru dan Peserta didik (Siklus I dan Siklus II)

Berdasarkan tabel dan diagram diatas, melalui perbaikan pembelajaran dengan menggunakan model pembelajaran mind mapping pada materi pristiwa alam di Indonesia oleh peneliti dikelas V SDN 1 Saka Lagun Kabupaten Kapuas aktivitas guru dan peserta didik menunjukkan perkembangan yang baik. Aktivitas guru dan peserta didik pada siklus I oleh pengamat 1 memperoleh nilai rata-rata 3 untuk aktivitas guru dan 2,8 untuk aktivitas peserta didik. Pengamat 2 memperoleh nilai rata-rata 3,06 untuk aktivitas guru dan 3,06 untuk aktivitas peserta didik.

Sedangkan pada siklus II ada peningkatan yang sangat baik, dengan penilaian oleh pengamat I memperoleh nilai rata-rata 3,7 untuk aktivitas guru dan 3,6 untuk aktivitas peserta didik. Pengamat II memperoleh nilai rata-rata 3,6 untuk aktivitas guru dan 3,6 untuk aktivitas peserta didik. Berdasarkan hasil tersebut dapat dilihat bahwa terjadi peningkatan aktivitas guru dan peserta didik dari siklus I ke siklus II. 
B. Hasil Belajar Peserta Didik Dalam Proses Pembelajaran
Tabel 2. Data Nilai Hasil Belajar (pre test, post test siklus I dan post test siklus II)

\begin{tabular}{|c|c|c|c|c|c|}
\hline No & Nama Peserta Didik & KKM & $\begin{array}{l}\text { Data } \\
\text { Awal } \\
\text { (Pre } \\
\text { Test) }\end{array}$ & $\begin{array}{l}\text { Siklus I } \\
\text { (Post Test) }\end{array}$ & $\begin{array}{l}\text { Siklus II } \\
\text { (Post Test) }\end{array}$ \\
\hline 1 & AW & 55 & 45 & 65 & 80 \\
\hline 2 & AA & 55 & 70 & 80 & 90 \\
\hline 3 & $\mathrm{~A}$ & 55 & 50 & 70 & 85 \\
\hline 4 & $\mathrm{ALF}$ & 55 & 30 & 40 & 50 \\
\hline 5 & $\mathrm{AZ}$ & 55 & 75 & 80 & 90 \\
\hline 6 & AY & 55 & 30 & 60 & 70 \\
\hline 7 & $\mathrm{AF}$ & 55 & 70 & 85 & 90 \\
\hline 8 & HT & 55 & 75 & 80 & 85 \\
\hline 9 & HD & 55 & 35 & 50 & 75 \\
\hline 10 & $\mathrm{I}$ & 55 & 60 & 75 & 80 \\
\hline 11 & $\mathrm{~J}$ & 55 & 45 & 70 & 80 \\
\hline 12 & $\mathrm{M}$ & 55 & 30 & 45 & 65 \\
\hline 13 & MA & 55 & 45 & 75 & 90 \\
\hline 14 & $\mathrm{MF}$ & 55 & 40 & 75 & 85 \\
\hline 15 & $\mathrm{~N}$ & 55 & 40 & 60 & 70 \\
\hline 16 & RMD & 55 & 60 & 70 & 80 \\
\hline 17 & RY & 55 & 30 & 50 & 70 \\
\hline 18 & WS & 55 & 65 & 80 & 90 \\
\hline 19 & $\mathrm{~S}$ & 55 & 55 & 65 & 80 \\
\hline \multicolumn{2}{|c|}{ Jumlah } & & 950 & 1275 & 1505 \\
\hline \multicolumn{2}{|c|}{ Rata-rata } & & 50 & 67 & 79 \\
\hline \multicolumn{2}{|c|}{ Persentase ketuntasan belajar } & & $42 \%$ & $79 \%$ & $95 \%$ \\
\hline
\end{tabular}

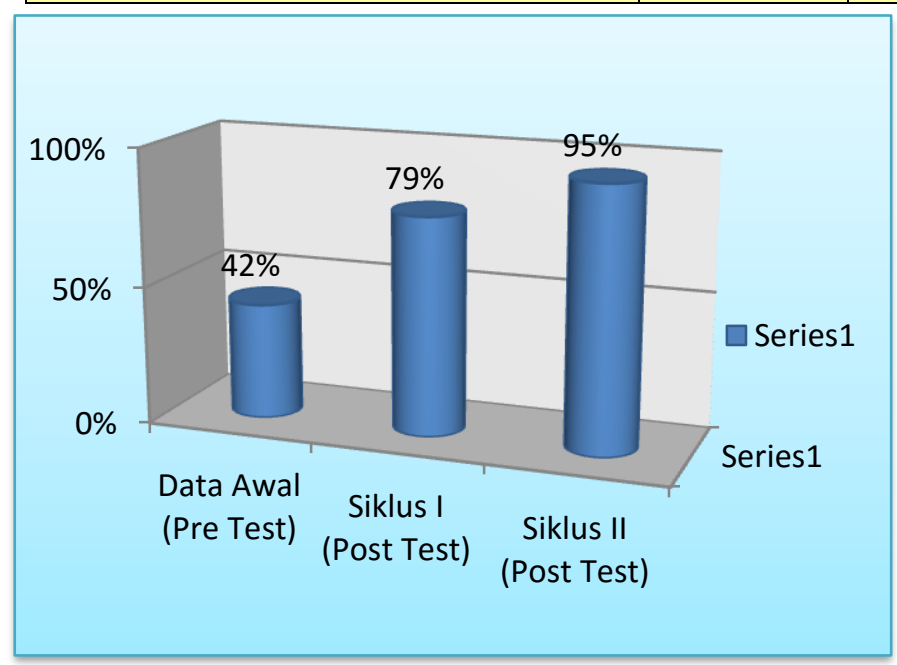




\section{Gambar. 2}

Diagram persentase ketuntasan belajar klasikal

Kelas V SDN Saka Lagun Kabupaten Kapuas

Berdasarkan tabel dan diagram diatas, maka didapat hasil data awal siklus I dan siklus II terlihat adanya peningkatan hasil belajar pada pelajaran IPA pada materi peristiwa alam di Indonesia dengan menggunakan model pembelajaran mind mapping pada kelas V SDN 1 Saka Lagun Kabupaten Kapuas. Dapat dilihat bahwa pada data awal peserta didik hanya memperoleh nilai rata-rata yaitu 50 , hal ini masih dibawah dari kriteria ketuntasan yaitu $\geq 55$. Hasil ketuntasan belajar peserta didik pun hanya memperoleh nilai sebesar $42 \%$. Nilai ini sangat jauh dari kriteria ketuntasan klasikal dimana nilai yang telah ditentukan yaitu $85 \%$.

Kemudian pada siklus I nilai ratarata peserta didik meningkat menjadi 67 nilai ini sudah mencapai kriteria ketuntasan minimum yang ditentukan. Hasil ketuntasan klasikal belajar peserta didik pun meningkat yakni memperoleh nilai $79 \%$, nilai ini hampir mencapai kriteria ketuntasan klasikal yang ditentukan yaitu $85 \%$. Sehingga harus mengoptimalkan lagi proses pembelajaran pada siklus II yang mana pada siklus II memperoleh nilai rata-rata 79 nilai ini mengalami peningkatan dari tindakan sebelumnya dan ketuntasan klasikalnya menjadi $95 \%$.

Berdasarkan hasil tersebut telah terjadi peningkatan hasil belajar IPA dengan menggunakan model pembelajaran mind mapping yaitu dari data awal dengan nilai rata-rata 50 dan ketuntasan klasikal $42 \%$, siklus I nilai rata-rata 67 dan ketuntasan klasikal 79\%, siklus II nilai rata-rata 79 dan ketuntasan klasikal 95\%. Sehingga dapat dilihat bahwa hasil belajar meningkat dari pra tindakan, siklus I dan siklus II.

\section{KESIMPULAN}

Berdasarkan data hasil penelitian yang telah dibahas, maka dapat disimpulkan :

1. Aktivitas belajar peserta didik kelas $\mathrm{V}$ SDN 1 Saka Lagun Kabupaten Kapuas dalam proses pembelajaran IPA dengan menggunakan model pembelajaran mind mapping menjadi lebih baik. Hal ini dibuktikan dengan hasil aktivitas peserta didik dalam mengikuti proses pembelajaran IPA dan dikategorikan baik dengan nilai rata-rata sebesar 2,9 pada sklus I dan meningkat menjadi 3,6 pada siklus II.

2. Ada peningkatan hasil belajar IPA dengan menggunakan model pembelajaran mind mapping pada peserta didik kelas V SDN 1 Saka Lagun Kabupaten Kapuas. Peningkatan tersebut dapat dilihat dari hasil belajar peserta didik pada mata pelajaran IPA khususnya pada materi peristiwa alam di Indonesia. Pada siklus I perolehan nilai rata-rata peserta didik 67 dengan ketuntasan klasikal $79 \%$ dan mengalami peningkatan pada siklus II dengan nilai rata-rata 79 dan ketuntasan klasikal 95\% dan KKM untuk kelas V SDN 1 Saka Lagun sebesar $\geq 55$.

\section{DAFTAR PUSTAKA}

Buzan, Tony. (2007). Buku Pintar Mind Mapping. Jakarta: PT Gramedia

Pustaka Utama

Dimyati dan Mudjiono.1999. Belajar dan Pembelajaran.Jakarta: Rineka 
Cipta

Dwi Siswoyo, dkk. (2007). Ilmu Pendidikan. Yogyakarta: UNY Pers

Hendra Surya. (2003). Kiat Mengajak Anak Belajar dan Berprestasi. Jakarta: Elex

Media Komputindo.

Hidayati. (2004). Pendidikan Ilmu Pengetahuan Sosial di Sekolah Dasar. Yogyakarta: IKIP Yogyakarta

Maskoeri Jasin. (2010).Ilmu Alamiah Dasar. Jakarta: Rajagrafindo Persada.

Nana Sudjana. (2004). Penilaian Hasil Proses belajar Mengajar. Bandung: PT

Remaja Rosdakarya.

Oemar Hamalik. (2001). Proses Belajar Mengajar. Bandung: PT Bumi Aksara. Patta

Prayitno Erman Amti. 1997. Dasardasar Bimbingan dan Konseling. Jakarta:

Depdikbud

Sri Sulistyorini. (2007). Model

Pembelajaran IPA Sekolah Dasar dan

Penerapannya dalam KTSP. Yogyakarta: Tiara Wacana.

Sugiyanto. (2012). Karakteristik Siswa SD. Jurnal Kependidikan Dosen UNY. HIm 1-7.

Sugihartono, dkk. (2007). Psikologi Pendidikan. Yogyakarta: UNY Press. Suharsimi

Surjani Wonorahardjo. (2010). Dasardasar Sains, Menciptakan Masyarakat Sadar Sains. Jakarta: Indeks.

Taufik Bahaudin. (1999) . Brainware Management. Jakarta: PT Elex Media Komputindo.

Usman Samatowo. (2006). Pembelajaran IPA di Sekolah Dasar. Jakarta. Bumi

Aksara. 